\title{
New records of scuttle flies (Diptera: Phoridae) from Iceland, with a survey of all simultaneously collected Dipteran families
}

\author{
Sabine Prescher, James Bonet \& Michael von Tschirnhaus
}

Prescher, S., Bonet, J. \& von Tschirnhaus, M. 2005: New records of scuttle flies (Diptera: Phoridae) from Iceland, with a survey of all simultaneously collected Dipteran families. - Entomol. Fennica 16: 237-245.

During a visit to Iceland in 2001, 727 specimens of Phoridae were caught. Seven species of Phoridae were identified, five of which were recorded from Iceland for the first time: Megaselia coccyx Schmitz, 1965; M. humeralis (Zetterstedt, 1838); M. parnassia Disney, 1986; M. quadriseta (Schmitz, 1941) and M. tarsicia Schmitz, 1926. The most abundant and most widespread phorid fly of the study was Megaselia coccyx, of which 510 specimens (70\% of the catch) on 18 of 29 sampling sites were caught. The female of Triphleba renidens Schmitz, 1927 is given an improved diagnosis, and the abdominal sternite 7 is illustrated for the first time. With the results of this study a total of 11 species of Phoridae have been identified from Iceland. Four of them were also recorded from Greenland and 3 from the Faroe Islands. An overview of all other 36 families of Diptera (more than 48,394 specimens) obtained during the same excursion to Iceland is also presented.

S. Prescher, Hinter der Masch 26, D-38114 Braunschweig, Germany; Email: s.prescher@gmx.de

J. Bonet, Swedish Museum of Natural History, Box 50007, SE-10405 Stockholm, Sweden; Email: james.bonet@nrm.se

M. von Tschirnhaus, Universität Bielefeld, Fakultät für Biologie, Postfach 100131,D-33501 Bielefeld, Germany; Email: m.tschirnhaus@uni-bielefeld.de

Received 11 February 2005, accepted 16 March 2003

\section{Introduction}

The Phoridae fauna of Iceland can be considered as being poorly known: a checklist of the fauna of this country lists only six species (Ólafsson 1991). Potentially many other Phoridae species can develop in the extreme conditions, although e.g. the capital Reykjavik has an average annual temperature of only $+5.1^{\circ} \mathrm{C}$. M. von Tschirnhaus, together with students of biology of the University of Bielefeld, Germany, carried out an excursion to Iceland in 2001, during which large numbers of insects were collected. This material, after having been sorted to family level, has been made available for scientific study. First results of the Diptera have been published by Kassebeer (2002) and of the Hymenoptera by Buhl (2002). In this paper, we present the extensive phorid material in detail.

\section{Material and methods}

A map showing the sampling sites is shown in Fig. 1. Table 1 gives details of the sites where Phoridae were caught. Altogether 30 and 5 


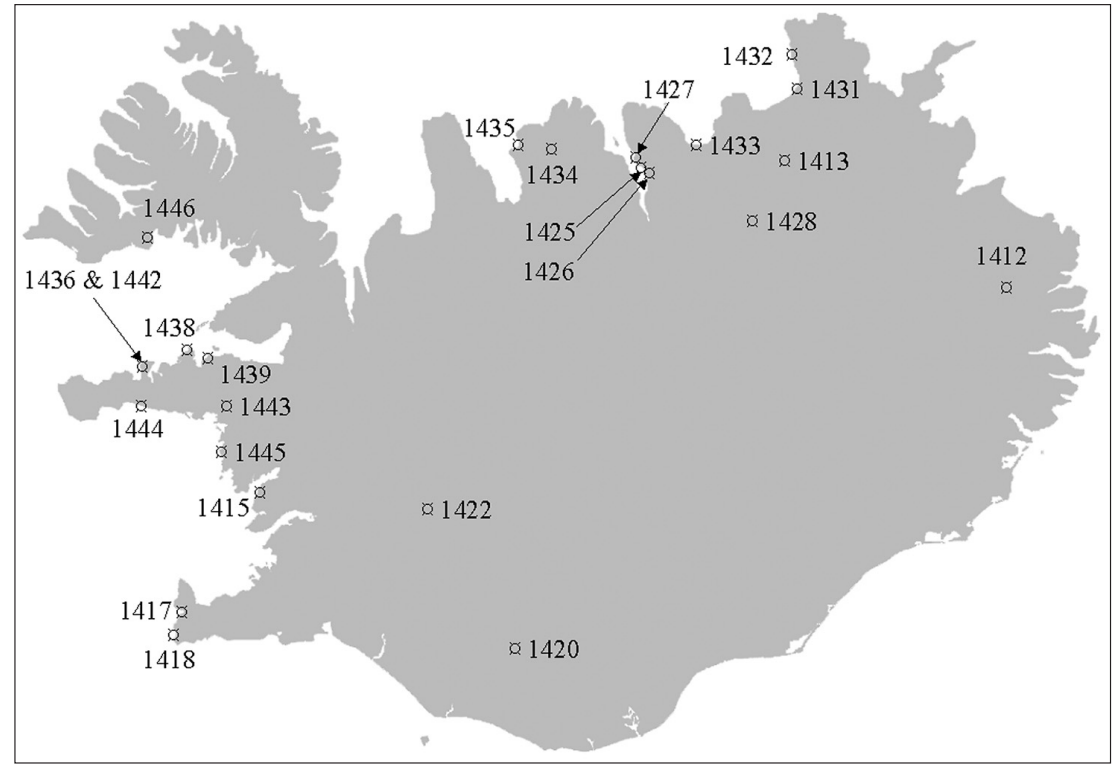

Fig. 1. Location of the sampling sites on Iceland (marked using circles). The numbers refer to Table 1 that provides further locality data. sweep-net samples of Diptera were collected by M. von Tschirnhaus and B. Rothe, respectively. One sweep-net sampling event (at one locality) normally lasted from 15 minutes to several hours; therefore, sample quantities are not directly comparable. Sweeping during dry weather was carried out above herbaceous, monocot, moss and lichen vegetation, and one sample was swept from birch branches. In a few cases flies were aspirated from the net, but mostly the sweep net was emptied directly into a wooden box through an opening that is sealed by a stopper. The interior of this box is blackened but is equipped with a transparent funnel on the tip, of which a transparent sampling container is fastened. Positively phototactic insects then fly towards the container and become preserved in $75 \%$ alcohol. Using this collecting method Diptera are not caught selectively (i.e. with a focus on certain families or sex), but according to their true abundance. Thus, the samples, in addition to the species composition, also reflect the absolute dominance of a taxon and the natural sex ratio of each species in the field.

The Phoridae of this study are deposited in the Swedish Museum of Natural History in Stockholm. Most of the other mentioned insects are stored to the Biological Collection of the Faculty of Biology, University of Bielefeld.

The preparation of the picture of sternite 7 of a single female of Triphleba renidens Schmitz,
1927 was made using the standard slide-mount procedure (Disney 1994), after which the mounted sample was photographed using Olympus SZX-12 digital camera. Thereafter, to enhance details, a hand-painted illustration was made based on the digital photograph and microscopic studies of the sternite 7. The picture of the wings of two T. renidens males was taken as follows. We first selected two specimens from the Iceland material that represented the maximum and minimum lengths of the costal subdivisions (see Discussion for further details); then, the slide-mount procedure followed by digital photography was applied, using the same camera as above.

\section{Results}

During the excursion, more than 48,394 Diptera were sampled. The identification to family level resulted in 11 Nematocera and 25 Brachycera families (Table 2). Most of the Nematocera belong to the family Chironomidae. In the suborder Brachycera, the Anthomyiidae, Muscidae, Coelopidae and Ephydridae were abundant.

Of the Phoridae, 729 individuals were caught. Six species of Megaselia Rondani and one of Triphleba Rondani were identified (Table 3), making up the total number of Icelandic Phoridae 
Table 1. List of sampling sites of Phoridae with information about the location, landscape and vegetation; positions are marked on map (Fig. 1).

\begin{tabular}{|c|c|c|c|c|}
\hline $\begin{array}{l}\text { Longitude/ } \\
\text { Latitude }\end{array}$ & $\begin{array}{l}\text { Nr. in } \\
\text { the map }\end{array}$ & $\begin{array}{l}\text { Date of } \\
\text { sampling }\end{array}$ & Location & Landscape and dominant vegetation \\
\hline $\begin{array}{l}65^{\circ} 16^{\prime} \mathrm{N} \\
14^{\circ} 25^{\prime} \mathrm{W}\end{array}$ & 1412 & 22.VI.01 & Egilsstaðir & Grassland \\
\hline $\begin{array}{l}65^{\circ} 56^{\prime} \mathrm{N} \\
16^{\circ} 33^{\prime} \mathrm{W}\end{array}$ & 1413 & 24-25.VI.01 & Jökulsárgljúfur National Park & $\begin{array}{l}\text { Diverse herbaceous vegetation with } \\
\text { Taraxacum, Juncus, Geranium }\end{array}$ \\
\hline $\begin{array}{l}64^{\circ} 30^{\prime} \mathrm{N} \\
21^{\circ} 55^{\prime} \mathrm{W}\end{array}$ & 1415 & 11.VII.01 & Eastern coast of Borgarfjörður & Betula forest and mountain grassland \\
\hline $\begin{array}{l}63^{\circ} 57^{\prime} \mathrm{N} \\
22^{\circ} 39^{\prime} \mathrm{W}\end{array}$ & 1417 & 16.VII.01 & $\begin{array}{l}\text { Western coast of Reykjanes } \\
\text { peninsula }\end{array}$ & $\begin{array}{l}\text { Salt marsh with Plantago maritima, } \\
\text { Angelica archangelica, Carex }\end{array}$ \\
\hline $\begin{array}{l}63^{\circ} 51^{\prime} \mathrm{N} \\
22^{\circ} 43^{\prime} \mathrm{W}\end{array}$ & 1418 & 16.VII.01 & $\begin{array}{l}\text { Western coast of Reykjanes } \\
\text { peninsula }\end{array}$ & $\begin{array}{l}\text { Brackish lake within dunes with } \\
\text { Rhinanthus minor, Parnassia } \\
\text { palustris, Ranunculus acer }\end{array}$ \\
\hline $\begin{array}{l}63^{\circ} 52^{\prime} \mathrm{N} \\
19^{\circ} 13^{\prime} \mathrm{W}\end{array}$ & 1420 & 22.VII.01 & Central Iceland & $\begin{array}{l}\text { Valley with Carex, Taraxacum, } \\
\text { Equisetum }\end{array}$ \\
\hline $\begin{array}{l}64^{\circ} 24^{\prime} \mathrm{N} \\
20^{\circ} 03^{\prime} \mathrm{W}\end{array}$ & 1422 & 23.VII.01 & Central Iceland & $\begin{array}{l}\text { Gravel plain with scattered } \\
\text { vegetation, mainly Deschampsia } \\
\text { beringensis and Festuca rubra }\end{array}$ \\
\hline $\begin{array}{l}65^{\circ} 54^{\prime} \mathrm{N} \\
18^{\circ} 05^{\prime} \mathrm{W}\end{array}$ & 1425 & 26.VII.01 & Delta of river Frijoská & $\begin{array}{l}\text { Fresh water marsh with Vicia, Euphrasia } \\
\text { hirtella, Rhinantus minor, Trifolium repens }\end{array}$ \\
\hline $\begin{array}{l}65^{\circ} 53^{\prime} \mathrm{N} \\
18^{\circ} 03^{\prime} \mathrm{W}\end{array}$ & 1426 & 26.VII.01 & $\begin{array}{l}\text { Mountain slopes } \\
\text { of the Stórihnjúkur }\end{array}$ & $\begin{array}{l}\text { Betula pubescens forest with Empetrum } \\
\text { nigrum, Vaccinium myrtillus, Pinguicola } \\
\text { vulgaris }\end{array}$ \\
\hline $\begin{array}{l}65^{\circ} 57^{\prime} \mathrm{N} \\
18^{\circ} 10^{\prime} \mathrm{W}\end{array}$ & 1427 & 27.VII.01 & Coast of Eyafjörður fjord & $\begin{array}{l}\text { Urban plot with swamp vegetation: } \\
\text { Hippuris vulgaris, Carex magellanicus, } \\
\text { Eriophorum scheuchzeri }\end{array}$ \\
\hline $\begin{array}{l}65^{\circ} 38^{\prime} \mathrm{N} \\
16^{\circ} 55^{\prime} \mathrm{W}\end{array}$ & 1428 & 28.VII.01 & $\begin{array}{l}\text { North eastern part } \\
\text { of lake Mývatn }\end{array}$ & $\begin{array}{l}\text { Shore with Carex, Caltha palustris, } \\
\text { Salix, Rumex, Galium }\end{array}$ \\
\hline $\begin{array}{l}66^{\circ} 12^{\prime} \mathrm{N} \\
16^{\circ} 28^{\prime} \mathrm{W}\end{array}$ & 1431 & 31.VII.01 & $\begin{array}{l}\text { Eastern shore of the mouth } \\
\text { of river Sandá }\end{array}$ & $\begin{array}{l}\text { Roadside along a lake. } \\
\text { Mainly Eleocharis on gravel ground }\end{array}$ \\
\hline $\begin{array}{l}66^{\circ} 23^{\prime} \mathrm{N} \\
16^{\circ} 31^{\prime} \mathrm{W}\end{array}$ & 1432 & 1.VIII.01 & Atlantic coast & $\begin{array}{l}\text { Mainly heather and grassland } \\
\text { with adjoining stony beach }\end{array}$ \\
\hline $\begin{array}{l}65^{\circ} 59^{\prime} \mathrm{N} \\
17^{\circ} 31^{\prime} \mathrm{W}\end{array}$ & 1433 & 2.VIII.01 & $\begin{array}{l}\text { South of the dune girdle along } \\
\text { the Atlantic coast }\end{array}$ & $\begin{array}{l}\text { Sandy ground with Leymus arenarius, } \\
\text { Juncus, Euphrasia, Ranunculus repens, } \\
\text { Rhinanthus minor }\end{array}$ \\
\hline $\begin{array}{l}65^{\circ} 58^{\prime} \mathrm{N} \\
18^{\circ} 59^{\prime} \mathrm{W}\end{array}$ & 1434 & $3-4 . \mathrm{VIII.01}$ & $\begin{array}{l}\text { Western slopes above } \\
\text { the lake Stifluvatn }\end{array}$ & $\begin{array}{l}\text { Wet slopes with diverse vegetation: } \\
\text { Poaceae, mosses, Alchemilla alpina, } \\
\text { Empetrum nigrum, Thymus praecox }\end{array}$ \\
\hline $\begin{array}{l}65^{\circ} 59^{\prime} \mathrm{N} \\
19^{\circ} 24^{\prime} \mathrm{W}\end{array}$ & 1435 & 4.VIII.01 & Eastern cost of Skagafjörður & $\begin{array}{l}\text { Sown young grass on flattened ground } \\
\text { along a viewpoint with Phleum pratense }\end{array}$ \\
\hline $64^{\circ} 59^{\prime} \mathrm{N}$ & 1436 & 6.VIII.01 & Northen coast of Snæfellnes & Beach flora and meadows with Poa- \\
\hline $23^{\circ} 14^{\prime} \mathrm{W}$ & 1442 & 7.VIII.01 & peninsula & $\begin{array}{l}\text { ceae, Ranunculus acer, Carex, Leon- } \\
\text { todon autumnalis, Rumex, comarum } \\
\text { palustre, Bistorta vivipara; bird excre- } \\
\text { ments by a colony of terns (Sterna) }\end{array}$ \\
\hline $\begin{array}{l}65^{\circ} 04^{\prime} \mathrm{N} \\
22^{\circ} 44^{\prime} \mathrm{W}\end{array}$ & 1438 & 6.VIII.01 & $\begin{array}{l}\text { Northen part of Snæfellnes } \\
\text { peninsula }\end{array}$ & $\begin{array}{l}\text { Herbaceous vegetation with Eriophorum } \\
\text { angustifolium, Ranunculus acer, } \\
\text { Equisetum, Leontodon autumnalis }\end{array}$ \\
\hline $\begin{array}{l}65^{\circ} 02^{\prime} \mathrm{N} \\
22^{\circ} 33^{\prime} \mathrm{W}\end{array}$ & 1439 & 6.VIII.01 & $\begin{array}{l}\text { Northen part of Snæfellnes } \\
\text { peninsula }\end{array}$ & $\begin{array}{l}\text { Wet grassland and ditches with } \\
\text { Equisetum arvense, Alchemilla alpina, } \\
\text { Ranunculus acer }\end{array}$ \\
\hline $\begin{array}{l}64^{\circ} 51^{\prime} \mathrm{N} \\
22^{\circ} 20^{\prime} \mathrm{W}\end{array}$ & 1443 & 9.VIII.01 & $\begin{array}{l}\text { Eastern part of Snæfellnes } \\
\text { peninsula }\end{array}$ & $\begin{array}{l}\text { Muddy swamp with Eleocharis, Carex, } \\
\text { Ranunculus repens, Poaceae }\end{array}$ \\
\hline $\begin{array}{l}64^{\circ} 50^{\prime} \mathrm{N} \\
23^{\circ} 15^{\prime} \mathrm{W}\end{array}$ & 1444 & 9.VIII.01 & $\begin{array}{l}\text { Southern part of Snæfellnes } \\
\text { peninsula }\end{array}$ & $\begin{array}{l}\text { Lake shore with diverse vegetation: } \\
\text { Carex, Luzula, Festuca vivipara, Leon- } \\
\text { todon autumnalis, Filipendula ulmaria }\end{array}$ \\
\hline $\begin{array}{l}64^{\circ} 38^{\prime} \mathrm{N} \\
22^{\circ} 23^{\prime} \mathrm{W}\end{array}$ & 1445 & 10.VIII.01 & Atlantic coast & $\begin{array}{l}\text { Diverse salt water influenced vegetation } \\
\text { with Vicia, Plantago maritima, } \\
\text { Euphrasia, Rhinanthus minor }\end{array}$ \\
\hline $\begin{array}{l}65^{\circ} 32^{\prime} \mathrm{N} \\
23^{\circ} 13^{\prime} \mathrm{W}\end{array}$ & 1446 & $2 . I X .01$ & $\begin{array}{l}\text { Southern coast of Barðaströnd } \\
\text { peninsula }\end{array}$ & $\begin{array}{l}\text { Heather along a footpath to an area } \\
\text { with fossils }\end{array}$ \\
\hline
\end{tabular}


Table 2. List of Diptera families and numbers of specimen caught in the study (Chironomidae were not completely counted). Nematocera $=$ family of Nematocera; Brachycera $=$ family of Brachycera.

\begin{tabular}{lrlr}
\hline Nematocera & Nr. individuals & Brachycera & Nr. individuals \\
\hline Bibionidae & 111 & Anthomyiidae, Muscidae & 6,571 \\
Cecidomyidae & 119 & Agromyzidae & 1,224 \\
Ceratopogonidae & 66 & Anthomyzidae & 167 \\
Chironomidae & 24,403 & Carnidae & 4 \\
Mycetophilidae & 205 & Chamaemyiidae & 31 \\
Psychodidae & 13 & Chloropidae & 484 \\
Simuliidae & 1,035 & Coelopidae & 2,370 \\
Tipulidae, Limoniidae & 450 & Dolichopodidae & 1,785 \\
Scatopsidae & 22 & Drosophilidae & 336 \\
Sciaridae & 673 & Empididae, Hybotidae & 788 \\
& & Ephydridae & 2,969 \\
& & Helcomyzidae & 438 \\
& & Heleomyzidae & 41 \\
& & Lonchopteridae & 65 \\
& & Pallopteridae & 11 \\
& & Phoridae & 727 \\
& & Piophilidae & 35 \\
& & Psilidae & 174 \\
& & Scatophagidae & 1,283 \\
& & Sciomyzidae & 16 \\
& & Sepsidae & 754 \\
& & Sphaeroceridae & 719 \\
& & Syrphidae & 305 \\
& & Total & 21,297 \\
\end{tabular}

to 11 (Table 4). The number of Phoridae on Iceland, the Faroe Islands and Greenland altogether now totals 18 (Table 4). Megaselia coccyx Schmitz, 1965 was the most abundant phorid in our study and accounted for about $70 \%$ of the total catch; M. pleuralis (Wood, 1909) was also abundant, found on five sites with a total of 100 specimens ( $14 \%$ of the catch); M. tarsicia Schmitz, 1926 formed $1.7 \%$ of the total catch (Table 3). The Megaselia females were not identified, as the only available determination key does not include females (Disney 1989), and the material did not allow a reliable association.

\section{Discussion}

Megaselia coccyx, the most abundant phorid in our samples, has striking morphological features such as a strongly inflated postero-dorsal region of the upper part of the hypopygium and a broad tarsal segment 5 . It has been found in the northern parts of Europe, e.g. from Scotland, Finland and
Sweden (Schmitz et al. 1938-1981; Weber \& Prescher 2004), but also in a laurel forest on Tenerife (Disney 1990). This is the first record for Iceland. M. coccyx was caught on 18 out of 29 sampling sites (Table 3), which makes it the most widely distributed species of Phoridae on Iceland. Megaselia coccyx occurred on all sampling sites on the Snæfellsnes Peninsula (sites 14361444) that is situated around the Snæfellsjökull glacier in western Iceland. This species was also the most abundant at three sampling sites on the northern coast of the Snæfellsness Peninsula. One site (1438) had diverse flowering dicotyledoneous vegetation. Other sampling sites (1436 and 1442) also had many flowering plants and additional bird excrement deposited by a colony of terns. However, nothing is known about the development and nutritional habits of the larvae of M. $\operatorname{coccyx}$.

Megaselia pleuralis, another abundant phorid, is widely distributed in Europe, including sites in the Alps 2,000 m above sea level (Schmitz et al. 1938-1981). The same authors have re- 
Table 3. Species list of the study sites on Iceland. For the position of the sampling sites, see Fig. 1. M. = Megaselia, $T .=$ Triphleba.

\begin{tabular}{|c|c|c|c|c|c|c|c|c|c|}
\hline $\begin{array}{l}\text { Site } \\
\text { nr. }\end{array}$ & $\begin{array}{c}M . \\
\operatorname{coccyx}\end{array}$ & $\begin{array}{c}M . \\
\text { humeralis }\end{array}$ & $\begin{array}{c}M . \\
\text { parnassia }\end{array}$ & $\begin{array}{c}\text { M. } \\
\text { pleuralis }\end{array}$ & $\begin{array}{c}M . \\
\text { quadriseta }\end{array}$ & $\begin{array}{c}M . \\
\text { tarsica }\end{array}$ & $\begin{array}{c}M . \\
\text { females }\end{array}$ & $\begin{array}{c}T . \\
\text { renidens }\end{array}$ & Total \\
\hline 1412 & - & - & 1 & - & - & - & - & 7 & 8 \\
\hline 1413 & - & - & - & - & - & - & 1 & - & 1 \\
\hline 1415 & 7 & - & - & - & - & - & - & 5 & 12 \\
\hline 1417 & - & - & - & 4 & - & - & - & - & 4 \\
\hline 1418 & 3 & - & - & - & - & - & 1 & - & 4 \\
\hline 1420 & - & 1 & - & - & - & 1 & - & 2 & 4 \\
\hline 1422 & 33 & - & - & - & - & - & 2 & - & 35 \\
\hline 1425 & 2 & - & - & 1 & - & - & 2 & - & 5 \\
\hline 1426 & 6 & - & - & - & - & - & 1 & - & 7 \\
\hline 1427 & 1 & - & - & - & - & - & 1 & 2 & 4 \\
\hline 1428 & - & - & - & - & - & - & 5 & - & 5 \\
\hline 1431 & 2 & - & - & - & - & - & 1 & - & 3 \\
\hline 1432 & 20 & - & 1 & 72 & - & 4 & 13 & 1 & 111 \\
\hline 1433 & 11 & - & - & - & - & 1 & - & - & 12 \\
\hline 1434 & 2 & - & - & - & - & 1 & 5 & 1 & 9 \\
\hline 1435 & 7 & - & - & - & - & - & - & - & 7 \\
\hline 1436 & 44 & - & - & 15 & - & 1 & 5 & - & 65 \\
\hline 1438 & 285 & - & 1 & - & - & 5 & 28 & - & 319 \\
\hline 1439 & 5 & - & - & - & 2 & - & 5 & - & 12 \\
\hline 1442 & 66 & - & - & 8 & - & - & 5 & - & 79 \\
\hline 1443 & 2 & 1 & - & - & - & - & 2 & - & 5 \\
\hline 1444 & 13 & - & - & - & 1 & - & 2 & - & 16 \\
\hline 1445 & - & - & - & - & - & - & 1 & - & 1 \\
\hline 1446 & 1 & - & - & - & - & - & - & - & 1 \\
\hline Total & 510 & 2 & 3 & 100 & 3 & 13 & 80 & 18 & 729 \\
\hline
\end{tabular}

corded M. pleuralis also from Iceland and Greenland. Many individuals were caught on a site in northern Iceland at the Atlantic coast, among heather and grass vegetation (1432). The larvae of $M$. pleuralis are known to have developed in pigeon dung (Disney 1994), in a compost heap (Werner 1997) and in dead spruce wood (B. Wermelinger, pers. comm.). These findings suggest a polysaprophagous diet of the larvae.

Megaselia tarsicia Schmitz, 1926 has striking features similiar to those of $M$. coccyx, but with only slightly inflated upper part of the hypopygium. Schmitz [in Schmitz et al. (1938-1981)] stated that M. tarsicia is montane in Central Europe; he often found specimens from the Austrian Alps 1,000 m above sea level. It has a boreo-alpine distribution and is known from Austria, Switzerland, Germany, Norway and Sweden (Weber \& Prescher 2004). In the present paper, the species is recorded for the first time from Iceland. The 12 specimens were caught on five sam- pling sites in August. Again, nothing is known about the development of the larvae.

Only one or two specimens of other Megaselia species were sampled. Megaselia humeralis (Zetterstedt, 1838) is easy to recognize by the greatly thickened costal wing vein (Disney 1989). It is widely distributed in Northern and Central Europe, including Scandinavia and Great Britain (Disney 1991, Weber \& Prescher 2004). In the present study, M. humeralis was found for the first time on Iceland. Its biology is unknown. Megaselia quadriseta Schmitz, 1918 belongs to the Megaselia giraudii-complex (Buck \& Disney 2001). This complex includes several species morphologically very similar to Megaselia giraudii (Egger, 1862) that is abundant in Central Europe (Buck \& Disney 2001). The same authors wrote that $M$. quadriseta "seems to replace the closely related Megaselia giraudii in boreo-alpine habitats of northern Europe". M. quadriseta is widely distributed in Central Europe (Weber \& 
Table 4. Distribution of Phoridae species caught on Iceland, Greenland and the Faroe Islands (Schmitz \& Beyer 1965, Disney 1991, 2004 and Weber \& Prescher 2004). Abbreviations for countries follow the standards used in Fauna Europaea (http://www.faunaeur.org). Ice = Iceland; Faroe = Faroe Islands; Green = Greenland.

\begin{tabular}{|c|c|c|c|c|}
\hline Species & Ice & Faroe & Green & Palaearctic and other regions \\
\hline $\begin{array}{l}\text { Diplonevra funebris } \\
\text { (Meigen, 1830) }\end{array}$ & No & Yes & No & $\begin{array}{l}\text { AT, BE, CH, CZ, DE, DK-FOR, ES-CNY, } \\
\text { ES-SPA, FI, FR-FRA, GB-GRB, GR, HU, } \\
\text { IRE, IT-ITA, NL, PL, PT-AZO, PT-MDR, } \\
\text { PT-POR, RU, SE, SK and YUYU; Nearctic }\end{array}$ \\
\hline Megaselia arcticae Disney, 2004 & No & No & Yes & Greenland \\
\hline $\begin{array}{l}\text { Megaselia cirriventris } \\
\text { Schmitz, } 1929\end{array}$ & No & No & Yes & $\begin{array}{l}\text { AT, ES-SPA, FI, FR, Greenland and SE; } \\
\text { Nearctic }\end{array}$ \\
\hline Megaselia clara (Schmitz, 1921) & Yes & No & Yes & $\begin{array}{l}\text { AT, CZ, FI, Greenland, IS, NO-NOR, PL } \\
\text { and SE; Nearctic }\end{array}$ \\
\hline Megaselia coccyx (Schmitz 1965) & Yes & No & No & DK-DEN, ES-CNY, FI, GB-GRB, IS and SE \\
\hline Megaselia giraudii (Egger, 1862) & Yes & No & No & $\begin{array}{l}\text { AT, BE, CH, CZ, DE, DK-DEN, ES-CNY, } \\
\text { ES-SPA, FI, FR-FRA, GB-GRB, HU, IS, } \\
\text { IT-ITA, NL, NO-NOR, PL, PT-POR, SE } \\
\text { and SK; Oriental and Nearctic Regions. }\end{array}$ \\
\hline $\begin{array}{l}\text { Megaselia groenlandica } \\
\text { (Lundbeck 1901) }\end{array}$ & No & No & Yes & $\begin{array}{l}\text { DK-DEN, FI, GB-GBR, Green-land, HU, } \\
\text { SE and SK; Nearctic }\end{array}$ \\
\hline $\begin{array}{l}\text { Megaselia humeralis } \\
\text { (Zetterstedt, 1838) }\end{array}$ & Yes & No & No & $\begin{array}{l}\text { AT, BE, CH, CZ, DE, DK-DEN, FI, GB- } \\
\text { GRB, HU, IRE, IS, NL, NO-NOR, PL, SE } \\
\text { and SK. }\end{array}$ \\
\hline Megaselia nigra (Meigen, 1830) & No & Yes & No & $\begin{array}{l}\text { AT, BE, BG, CH, CZ, DE-DK-DEN, DK- } \\
\text { FOR, ES-CNY, ES-SPA, FI, FA-FRA, GB- } \\
\text { GRB, HU, IRE, NL, NO-NOR, PL, PT- } \\
\text { AZO, PT-MDR, PT-POR, RU, SE and SK; } \\
\text { Nearctic Region }\end{array}$ \\
\hline Megaselia parnassia Disney, 1986 & Yes & No & No & DE, GB-GRB, IS and SE \\
\hline Megaselia pleuralis (Wood, 1909) & Yes & No & Yes & $\begin{array}{l}\text { AT, BE, BG, CH, CZ, DE, DK-DEN, ES- } \\
\text { CNY, ES-SPA, FI, FR-FRA, GB-GRB, } \\
\text { Greenland, HU, IRE, IS, IT-ITA, NL, NO- } \\
\text { NOR, PL, PT-AZO, PT-MDR, PT-POR, } \\
\text { RO, RU, SE, SK and YUYU; Nearctic Region }\end{array}$ \\
\hline Megaselia pumila (Meigen, 1830) & Yes & Yes & No & $\begin{array}{l}\text { AT, BE, CH, CZ, DE, DK-DEN, DK-FOR, } \\
\text { ES-SPA, FI, FR-FRA, GB-GRB, HU, IRE, } \\
\text { IS, IT-ITA, NL, NO-NOR, PL, PT-POR, RU } \\
\text { SE, SK and YUYU. }\end{array}$ \\
\hline $\begin{array}{l}\text { Megaselia quadriseta } \\
\text { (Schmitz, 1918) }\end{array}$ & Yes & No & No & $\begin{array}{l}\text { AT, CZ, DE, DK-DEN, GB-GRB, HU, NL, } \\
\text { PL, PT-MDR, PT-POR, SK and IS }\end{array}$ \\
\hline Megaselia rufipes (Meigen, 1804) & No & Yes & Yes & $\begin{array}{l}\text { AT, BE, CH, CZ, DE, DK-DEN, DK-FOR, } \\
\text { ES-CNY, ES-SPA, FI, FR-FRA, GB-GRB, } \\
\text { Greenland, HU, IRE, IT-ITA, IT-SI, NL, } \\
\text { NO-NOR, PL, PT-AZO, PT-MDR, PT- } \\
\text { POR, RU, SE, SK and YUYU; Afrotropical, } \\
\text { Australasian, Nearctic and Neotropical } \\
\text { Regions }\end{array}$ \\
\hline $\begin{array}{l}\text { Megaselia sordida } \\
\text { (Zetterstedt, 1838) }\end{array}$ & Yes & Yes & No & $\begin{array}{l}\text { AT, BE, CH, CZ, DE, DK-FOR, ES-SPA, } \\
\text { FI, FR-FRA, GB-GRB, HU, IS, IT-ITA, NO- } \\
\text { NOR, PL, RU, SE and SK; Nearctic Region }\end{array}$ \\
\hline Megaselia tarsicia Schmitz, 1926 & Yes & No & No & $\begin{array}{l}\text { AT, CH, CZ, DE, DK-DEN, IS, NO-NOR, } \\
\text { PL, SE and SK. }\end{array}$ \\
\hline Triphleba gracilis (Wood, 1907) & No & Yes & No & $\begin{array}{l}\text { AT, DE, DK-DEN, DK-FOR, FI, GB-GRB, } \\
\text { HU, IRE, PL, SE and SK. }\end{array}$ \\
\hline Triphleba renidens Schmitz, 1927 & Yes & No & No & AT, BE, FI, GB-GRB, IS, NL, RU and SE \\
\hline
\end{tabular}




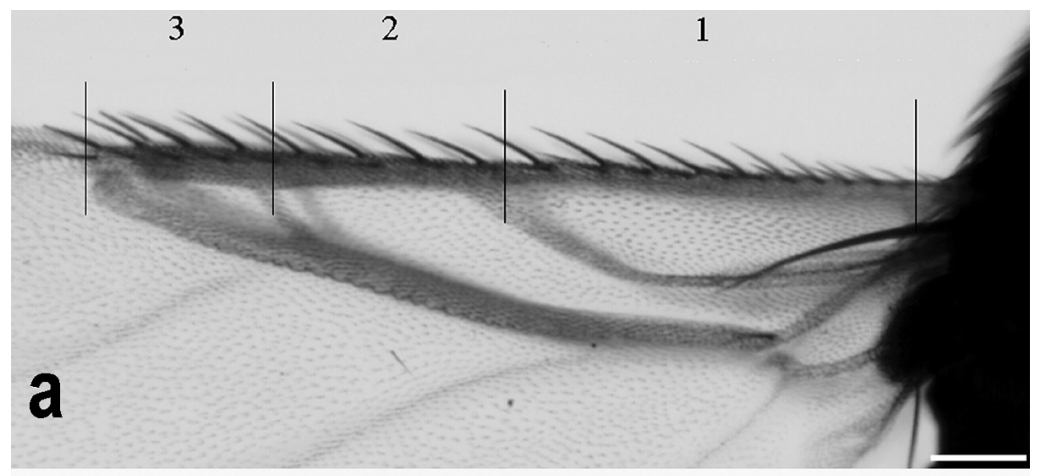

3

2

1

Fig. 2. Triphleba renidens. Males, right wing, ventral view, showing variation in size of the costal subdivisions 1 and $2+3$. Costal subdivision 1 can be equal to (a) or longer than (b) the combined length of the costal subdivisions $2+3$. Scale bars $100 \mu \mathrm{m}$.

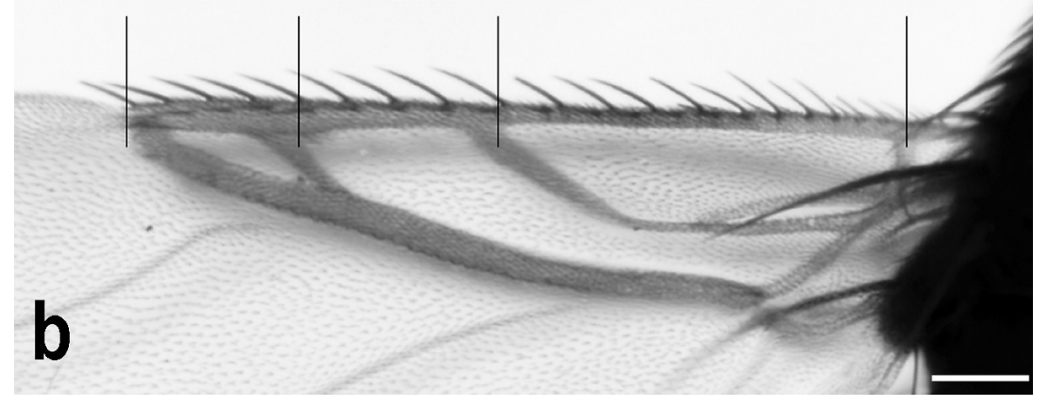

Prescher 2004), but it has not previously been found on Iceland. Larvae of M. quadriseta have developed in carrion traps baited with kidney and dead snails, and on lignicolous fungi (Buck 1997). Megaselia parnassia Disney, 1986 belongs, like $M$. quadriseta, to the Megaselia giraudii-complex, and has been recorded from Germany, Great Britain, Norway and Sweden (Disney 1991, Weber \& Prescher 2004). Larvae of M. parnassia appear to be zoosaprophagous, having been found in carrion traps with kidney (Buck 1997).

Iceland is situated almost midway between Greenland (300 km to the west) and the Faroe Islands (450 km to the southeast); bioclimatically it falls in between the arctic Greenland and the atlantic/boreal Faroe Islands (Elvebakk et al. 1999). Comparing the phorid fauna of these three areas, however, reveals an overlap in five cases, but with no species simultaneously present on all three islands (Table 4). The species shared between Iceland and the Faroe Islands are Megaselia pumila (Meigen, 1830) and Megaselia sordida (Zetterstedt, 1838). Megaselia clara (Schmitz, 1921) and Megaselia pleuralis (Wood, 1909) are shared between Iceland and Greenland.
Although some of the species encountered on these islands show a wide Palaearctic or Nearctic distribution (Table 4), about half of the species on each island have been caught on only one island; hence, no overlap is shown (Table 4: Iceland 6 of 11, Faroe Islands 3 of 6 and Greenland 3 of 6 species). The distribution of Megaselia pleuralis and the cosmopolitan Megaselia rufipes (Meigen, 1804) (Schmitz et al.1938-1981) indicates that even more species are likely to be encountered on Iceland. These two species show a partial overlap among the northern Atlantic islands, but a complete overlap in the Canary Islands, the Azores and Madeira (Table 4). This suggests a more extensive distribution on Iceland, the Faroe Islands and Greenland. M. rufipes that is shared between the Faroe Islands and Greenland has not yet been recorded from Iceland but should also be expected to occur there.

Apart from Megaselia, only one additional genus was encountered on Iceland, containing only one species, viz. Triphleba renidens Schmitz, 1927. A total of 16 individuals was caught, including a single female that is considered here conspecific with the males (see below). According to Schmitz et al. (1938-1981), this 
species has been found in Finland, Belgium, and The Netherlands. Additional findings have been made in Austria, Great Britain, Iceland, Sweden and Russia (Disney 1991, Weber \& Prescher 2004). In this study, T. renidens was represented in five sampling sites among various types of habitats such as grassland, swamps and Betula forest (sites 1412, 1415, 1427, 1432 and 1434). In The Netherlands, T. renidens is active in spring, but in the northern part of its distribution the active period appears to be more extended (Schmitz et al.1938-1981). Nothing is known about the biology of the larvae.

The male of Triphleba renidens is easily distinguished by the elongated left process of the epandrium; with a gently-curved hind margin and the basal part with a deep incision located at a centro-lateral position on the epandrium [see figure 113f in Schmitz et al. (1938-1981) and figure 2 in Disney (2001)]. T. renidens is furthermore distinguished by the shiny frons, as considered by Schmitz et al. (1938-1981) in their key to the Palaearctic species and in Disney (2001). However, the male specimens from the Iceland material occasionally key out incorrectly in Schmitz et al. [(1938-1981); page 140, key entry no. 23], at the key entry comparing the relative length of the three costal subdivisions [Schmitz et al. (19381981): page 47, figure text 44; see also Disney (1994): page 210, figure 8.5]. This is probably due to the fact that Schmitz et al. (1938-1981) did not realise the variability of the relative length measures of the subdivision of costa among $T$. renidens (Fig. 2a-b). This may also be the case for the single female specimen of $T$. renidens of the present study, which in Schmitz et al. (19381981) keys out as Triphleba lyria Schmitz, 1935. Additional facts supporting the finding of a female $T$. renidens are the shape of the sternite 7 (illustrated for the first time in Fig. 3), which is in close agreement with the description in Schmitz et al. (1938-1981): large, shovel-shaped, and with a hind margin that is broad and gently curved (see also Disney 2001). As only one species of Triphleba has been found on Iceland (Ólafsson 1991, present paper), we favour the hypothesis that the single Triphleba female is a T. renidens.

More Phoridae males (510) than females (80) were caught using the sweep net method. A predominance of males was also found in catches of

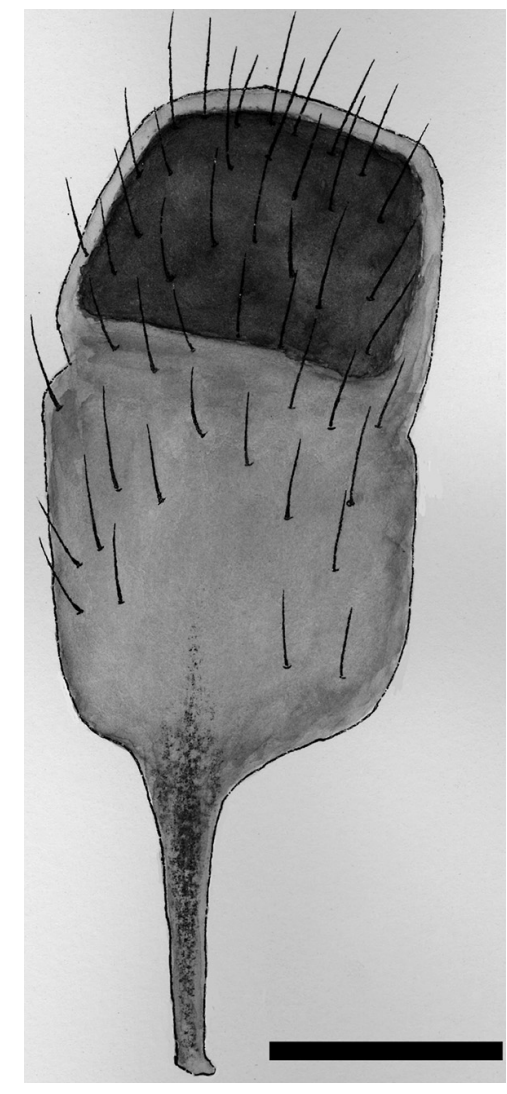

Fig. 3.

Triphleba

renidens.

Female

sternite 7

Scale bar

$100 \mu \mathrm{m}$.

emergence traps, sticky traps and suction traps (Disney 1994). Disney (1994) stated that the unbalanced sex ratio reflected difference in behaviour of the sexes. The males of many Phoridae species are more prone to dispersal than the females.

Acknowledgements. We thank Thomas Pape for valuable comments and qritique on earlier versions of the manuscript. S. Prescher acknowledges funding through the High Lat programme that was made available by the European Community - Access to Research Infrastructure Action of the Improving Human Potential Programme.

\section{References}

Buck, M. 1997: Untersuchung zur ökologischen Einnischung saprophager Dipteren unter besonderer Berücksichtigung der Phoridae und der Sphaeroceridae (Diptera/Cyclorrhapha). — Dissertation, Universität Ulm. 194 pp.

Buck, M. \& Disney, R. H. L. 2001: Revision of the Megaselia giraudii and $M$. densior species complexes of Europe, including ecological notes (Diptera, 
Phoridae). — Beiträge zur Entomologie 51(1): 73154.

Buhl, P. N. 2002: Proctotrupoidea s.l. and Ceraphronoidea from Iceland: new records and corrections (Hymenoptera). — Entomologiske Meddelelser 70: 77-80.

Disney, R. H. L. 1989: Scuttle flies. Diptera, Phoridae. Genus Megaselia. - Handbooks for the Identification of British Insects Vol. 10, Part 8, Royal Entomological Society of London. $155 \mathrm{pp}$.

Disney, R. H. L. 1990: A revised list of Phoridae (Diptera) from the Canary Islands, with habitat notes. - Vieraea 18: 261-265.

Disney, R. H. L. 1991: Family Phoridae. — In: Soós, A. \& Papp, L. (1991), Catalogue of Palaearctic Diptera, Volume 7, Akadémiai Kiadó, Budapest. 291 pp.

Disney, R. H. L. 1994: Scuttle Flies: The Phoridae. Chapman \& Hall, London. 467 pp.

Disney, R. H. L. 2001: A scuttle Fly (Diptera: Phoridae) New to Britain caught in a net suspended 200 meters above the ground. - British Journal of Entomology and Natural History 14: 39-43.

Disney, R. H. L. 2004: A new species of Megaselia Rondani (Dipt., Phoridae) from Arctic Greenland. - Entomologist's Montly Magazine 140: 309-312.

Elvebakk, A., Elven, R., \& Razzhivin, V. Yu. 1999: Delimitation, zonal and sectorial subdivision of the Arctic.
— Det Norske Videnskaps-Akademi. I. Mat. Naturv. Klasse, Skrifter, ny Serie 38: 375-386.

Kassebeer, C. F. 2002: Neue Nachweise von Hornfliegen/Diptera, Sciomyzidae aus Island. — Dipteron 4(2): 209-212.

Ólafsson, E. 1991: Íslenskt skordýratal. — Fjölrit Náttúrufraeðistofnunar 17: 1-69.

Schmitz, H.; Beyer, H. \& Delage, A. 1938-1981: 33. Phoridae. - In: Lindner, E. (ed.): Die Fliegen der paläarktischen Region, Vol. 8(9), Stuttgart. 712 pp.

Schmitz, H. \& Beyer, E. 1965: Family Phoridae. — In: Stone, A.; Sabrosky, C. W.; Wirth, W. W.; Foote, R. H.; \& Coulson, J. R. (eds.): A Catalog of the Diptera of America north of Mexico. Agricultural Research Service, United States Department of Agriculture, Handbook 276, Washington, D.C. iv + 1696 pp.

Weber, G. \& Prescher, S. 2004: Fauna Europaea: Phoridae. - In: Pape, T. (ed.), Fauna Europaea: Diptera, Brachycera. Fauna Europaea version 1.1. Available at http://www.faunaeur.org.

Werner, D. 1997: Die Dipterenfauna verschiedener Mülldeponien und Kompostierungsanlagen in der Umgebung von Berlin unter besonderer Berücksichtigung ihrer Biologie und Bionomie. - Studia dipterologica, Supplement 1, Halle/Saale. 176 pp. 